\title{
Этносоциальные особенности занятости населения в республиках Тува и Башкортостан
}

\author{
Рим М. Валиахметов \\ Башкирский государственный университет, Российская Федерация, \\ Гузель Р. Баймурзина \\ Башкирский филиал ФНИСЦ РАН; Башкирский государственный университет, Российская Федерация, \\ Марсель С. Туракаев \\ Башкирский государственный университет; Башкирский филиал ФНИСЦ РАН, Российская Федерация, \\ Анна Д.-Б. Самба \\ Институт социологии ФНИСЦ РАН, Российская Федерация
}

Статья посвящена сравнительному анализу особенностей занятости в двух республиках Российской Федерации Башкортостане и Туве. Они отличаются друг от друга, в том числе структурой экономики, темпом модернизации, человеческому потенциалу, этническому составу населения. Тем не менее, обе являются республиками с титульным этносом и обладают выраженными этносоциальными особенностями развития. Анализируются этносоциальные особенности занятости населения республики, трудовой мобильности, в том числе выявляемые в оценках самих жителей. Источниковой базой выступают статистические данные, а также материалы социологического исследования авторов «Этнические особенности развития человеческого потенциала в экономиках республик Российской Федерации", проведенного в обеих республиках в 2021 г. Выборка репрезентативная.

Выяснилось, что жители Тувы сравнительно больще ценят этническую принадлежность, чем жители Башкортостана. Ценность и важность этнической принадлежности для жителей Тувы и Башкортостана падает заметно, если их трудовая занятость осуществляется в условиях неустойчивой, временной работы. Ценность этнической принадлежности связана с уверенностью в устойчивости своей позиции на рынке труда. Жители Тувы, уверенные в том, что не потеряют свою работу, чаще заявляют о важности своей национальности, чем респонденты из Башкортостана.

Этническая принадлежность, по мнению опрошенных жителей двух республик, влияет на возможности расширения образовательных стратегий, успешного трудоустройства и хорошо оплачиваемой работы, а также на возможность открыть и вести свое дело. По мнению респондентов, возможности для карьерного роста и повышения своей квалификации сравнительно выше в Республике Башкортостан, чем в Республике Тува. При этом башкиры меньше удовлетворены возможностями развития в трудовой сфере, чем представители других национальностей Башкортостана. Тувинцы больше довольны возможностями карьерного роста, чем русские Республики Тува, однако здесь и русские, и тувинцы одинаково оценивают перспективы получения образования и повышения своей квалификации.

Ключевые слова: занятость; этносоциальный фактор; трудовой статус; уровень жизни; социальная структура; социокультурный фактор; Республика Тува; Республика Башкортостан; тувинцы; башкиры; русские Тувы

Статья подготовлена в рамках Программы фундаментальных и прикладных научных исследований «Этнокультурное многообразие российского общества и укрепление общероссийской идентичности» (2020-2022 г2.).

Для цитирования:

Валиахметов Р. М., Баймурзина Г. Р., Туракаев М. С., Самба А. Д.-Б. Этносоциальные особенности занятости населения в республиках Тува и Башкортостан // Новые исследования Тувы. 2021, № 4. C. 206-222. DOI: https://www. doi.org/10.25178/nit.2021.4.15

Валиахметов Рим Марсович - кандидат социологических наук, декан факультета философии и социологии, заведующий научной лабораторией социальных и демографических исследований Башкирского государственного университета. Адрес: 450076, Россия, г. Уфа, ул. Карла Маркса, д. 3/4. Тел.: +7 (963) 898-61-48. Эл. адрес: rim_m_sifat@inbox.ru

Баймурзина Гузель Римовна - кандидат экономических наук, директор Башкирского филиала Федерального научно-исследовательского социологического центра Российской академии наук; ведущий специалист Научной лаборатории социальных и демографических исследований, Башкирского государственного университета. Адрес: 450005, Россия, г. Уфа, ул. 50-летия Октября, д. 20/1. Тел.: +7 (917) 755-99-74. Эл. адрес: guzrim@mail.ru

Туракаев Марсель Салаватович - кандидат социологических наук, старший преподаватель кафедры социологии и работы с молодежью факультета философии и социологии Башкирского государственного университета; старший научный сотрудник Башкирского филиала Федерального научно-исследовательского социологического центра РАН. Адрес: 450076, Россия, г. Уфа, ул. Карла Маркса, д. 3/4. Тел.: +7 (965) 656-28-82. Эл. адрес: mturakaev@gmail.com

Самба Анна Демир-Баадыровна - младший научный сотрудник Института социологии Федерального научно-исследовательского социологического центра Российской академии наук. Адрес: 117218, Россия, г. Москва, ул. Кржижановского, д. 24/35, к. 5. Тел.: +7 (995) 550-56-56. Эл. адрес: sundui2012@yandex.ru 


\title{
Ethnic and Social Features of Employment in the Republics of Tuva and Bashkortostan
}

\author{
Rim M. Valiakhmetov \\ Bashkir State University, Russian Federation, \\ Guzel R. Baimurzina \\ Bashkir Branch of the FCTAS RAS; Bashkir State University, Russian Federation, \\ Marcel S. Turakayev \\ Bashkir State University; Bashkir Branch of the FCTAS RAS, Russian Federation, \\ Anna D.-B. Samba \\ Institute of Sociology of the FCTAS RAS, Russian Federation
}

\begin{abstract}
The article deals with a comparative analysis of the features of employment in two republics of the Russian Federation - Bashkortostan and Tuva. They differ from each other in the structure of the economies, the pace of modernization, human potential, and the ethnic composition of the population. Nevertheless, they both are republics with titular ethnic groups, and they have overt ethnic and social characteristics of the development. The authors analyze the ethnic and social features of the population's employment in the republics and of labor mobility, including those revealed in assessments of the residents. The source base of the research comprises statistical data and materials of the authors' sociological survey "Ethnic Features of Human Potential Development in the Economies of the Republics of the Russian Federation" that was conducted in both republics in 2021. The sample was representative.

It has turned out that residents of Tuva estimate their ethnicity comparatively higher than the people of Bashkortostan. The value and significance of ethnicity for inhabitants of Tuva and Bashkortostan decline considerably if they work in precarious employment conditions (casual labor). The value of ethnicity is connected with confidence in the sustainability of one's position in the labor market. Residents of Tuva who are sure that they will not lose their jobs declare the significance of their nationality more often than respondents from Bashkortostan.

In the opinion of the respondents from the two republics, ethnic background affects the possibilities for expanding educational strategies, a successful employment, a well-paid job and an opportunity to start and run a small business. According to the respondents, opportunities for career growth and professional development are relatively higher in the Republic of Bashkortostan than in the Republic of Tuva. At the same time, the Bashkirs are less satisfied with their opportunities for development in the labor sphere than representatives of other nationalities of Bashkortostan. The Tuvans are more pleased with their career opportunities than the Russians in the Republic of Tuva, but both the Russians and Tuvans equally assess the prospects for acquiring an education and improving their qualifications.

Keywords: employment; ethnic and social factor; labor status; standard of living; social structure; sociocultural factor; Republic of Tuva; Republic of Bashkortostan; Tuvans; Bashkirs; Russians in Tuva
\end{abstract}

\section{Financing}

The article was prepared within the framework of the Program of Fundamental and Applied Research "Ethnocultural Diversity of Russian Society and Consolidation of the All-Russian Identity" (2020-2022).

\section{For citation:}

Valiakhmetov R. M., Baimurzina G. R., Turakayev M. S. and Samba A. D.-B. Etnosotsial'nye osobennosti zaniatosti naseleniia $\mathrm{v}$ respublikakh Tuva i Bashkortostan [Ethnic and Social Features of Employment in the Republics of Tuva and Bashkortostan]. New Research of Tuva, 2021, no. 4, pp. 206-222 (In Russ.). DOI: https://www.doi.org/10.25178/nit.2021.4.15

VALIAKHMETOV, Rim Marsovich, Candidate of Sociology, Dean, Faculty of Philosophy and Sociology; Head, Scientific Laboratory of Social and Demographic Research, Bashkir State University. Postal address: $3 / 4$ Karl Marx St., 450076 Ufa, Russian Federation. Tel.: +7 (963) 898-61-48. E-mail: rim_m_sifat@inbox.ru

ORCID ID: 0000-0002-8875-5197

BAIMURZINA, Guzel Rimovna, Candidate of Economics, Director, Bashkir Branch of the Federal Center of Theoretical and Applied Sociology, Russian Academy of Sciences; Leading Specialist, Scientific Laboratory of Social and Demographic Research, Bashkir State University. Postal address: 20/1, 50th Anniversary of October St., 450005 Ufa, Russian Federation. Tel.: +7 (917) 755-99-74. E-mail: guzrim@mail.ru

ORCID ID: 0000-0002-1844-2689

TURAKAYEV, Marcel Salavatovich, Candidate of Sociology, Senior Lecturer, Department of Sociology and Youth Work, Faculty of Philosophy and Sociology, Bashkir State University; Senior Researcher, Bashkir Branch of the Federal Center of Theoretical and Applied Sociology, Russian Academy of Sciences. Postal address: 3/4 Karl Marx St., 450076 Ufa, Russian Federation. Tel.: +7 (965) 656-28-82. E-mail: mturakaev@gmail.com

SAMBA, Anna Demir-Baadyrovna, Junior Research Fellow, Institute of Sociology of the Federal Center of Theoretical and Applied Sociology, Russian Academy of Sciences. Postal address: Bldg. 5, 24/35 Krzhizhanovskogo St., 117218 Moscow, Russian Federation. Tel.: +7 (995) 550-56-56. E-mail: sundui2012@yandex.ru 


\section{Введение}

Современный этап социально-экономического развития России характеризуется неравномерностью в региональном аспекте, обусловленной в том числе этносоциальными и этнокультурными особенностями каждого региона. Так, Н. И. Лапин, один из ведущих российских исследователей социокультурной модернизации страны, убедительно доказывает необходимость изучения и учета социокультурных характеристик и особенностей регионов для наращивания и максимально эффективного использования человеческого потенциала каждого жителя страны (Лапин, 2014: 11). С этой точки зрения, например, реализация в Туве проектов «Кыштаг - для молодой семьи» ${ }^{1}$; «дно село - один продукт»²; «Корова - кормилица» ${ }^{3}$, направленные на поддержку сельского хозяйства и животноводства, традиционного в регионе, являются примером учета региональной специфики, механизмом вовлечения жителей села в экономические отношения и эффективного использования человеческого потенциала. Немало таких примеров и в Республике Башкортостан, где имеются региональные программы по развитию пчеловодства и бортничества, коневодства и кумысолечения.

Республика Тува и Республика Башкортостан существенно отличаются друг от друга по разным параметрам: по природно-климатическим условиям развития, экономико-географическому положению, структуре экономики, темпам модернизации, человеческому потенциалу и др. Республика Башкортостан относится к средне развитым регионам с опорой на добывающую промышленность, в то время как Республика Тува относится к регионам с уровнем модернизации ниже среднего Башкортостан - полиэтничный регион, в котором примерно в одинаковых пропорциях представлены три наиболее многочисленных этноса - башкиры $(29,5 \%)$, татары $(25,4 \%)$ и русские (36,0\%) Республика Тува по своему этническому составу больше моноэтническая с преобладанием коренного населения - тувинцев $(82 \%)^{6}$.

Республики Тува и Башкортостан выбраны для сравнения, исходя из авторского подхода к двум субъектам как к «двум разным полюсам» развития, позволяющим в сопоставлении получать больший объем надежной информации для научного анализа. Соответственно, для научного знания актуальным становится изучение этносоциальных особенностей как каждой из республик в отдельности, так и в соотношении с другими регионами, а также с общероссийскими тенденциями.

Целью данной работы является выявление этносоциальных особенностей - общего и различного - в основных видах экономической деятельности и занятости населения в республиках Тува и Башкортостан.

Объектом исследования является трудоспособное население республик, предметом - этносоциальные особенности его занятости, трудовой мобильности, в том числе выявляемые в оценках самих жителей республик.

\footnotetext{
${ }^{1}$ В Туве заработает антикризисный проект под названием «Кыштаг для молодой семьи» [Электронный ресурс] // Официальный портал Республики Тыва. URL: https://rtyva.ru/press_center/news/agriculture/21722/ (дата обращения: 11.09.2021).

${ }^{2}$ Одно село - один продукт - 2015: итоги, победители, прибыль [Электронный ресурс] // Официальный портал Республики Тыва. URL: https://rtyva.ru/press_center/news/economy/21376/ (дата обращения: 11.09.2021); Глава Тувы направил проект «Одно село - один продукт» по пути создания аграрных кластеров [Электронный ресурс] // Официальный портал Республики Тыва. URL: https://rtyva.ru/press_center/news/agriculture/12981/ (дата обращения: 11.09.2021).

${ }^{3}$ Информация о ходе реализации социального проекта «Корова-кормилица» [Электронный ресурс]// Официальный портал Республики Тыва. URL: https://rtyva.ru/press_center/news/municipalities/37367/ (дата обращения: 11.09.2021). ${ }^{4}$ Атлас модернизации России и ее регионов: социоэкономические и социокультурные тенденции и проблемы / сост. и отв. ред. член-корр. РАН Н. И. Лапин. М.: Издательство «Весь Мир», 2016. 360 с. С. 40 [Электронный ресурс] // Институт философии PAH. URL: https://iphras.ru/uplfile/scult/analit/atlas_regionov.pdf (дата обращения: 20.09.2021). ${ }^{5}$ Национальный состав населения Республики Башкортостан по данным Всероссийской переписи населения 2010 года: статистический бюллетень. Уфа: Башкортостанстат, 2012. С. 30. [Электронный ресурс] // Территориальный орган Федеральной службы государственной статистики по Республике Башкортостан. URL: https:// bashstat.gks.ru/storage/mediabank/Национальный+состав+населения+Республики+Башкортостан(1).pdf (дата обращения: 15.09.2021).

${ }^{6}$ Национальный состав населения Республики Тыва [Электронный ресурс] // Управление федеральной службы государственной статистики по Красноярскому краю, Республике Хакасии и Республике Тыва. URL: https://krasstat. gks.ru/storage/mediabank/Статья.htm (дата обращения: 04.09.2021).
} 
Соответственно источниковой базой исследования выступают официальные, опубликованные статистические данные, а также материалы социологического исследования, проведенного авторами статьи в обеих республиках в 2021 г. Исследование «Этнические особенности развития человеческого потенциала в экономиках республик Российской Федерации» было реализовано в рамках всероссийской Программы фундаментальных и прикладных научных исследований «Этнокультурное многообразие российского общества и укрепление общероссийской идентичности» (2020-2022 гг.) в мае-июне (в Туве) и сентябре 2021 г. (в Башкортостане). Объем выборки в Республике Тува составил 1176 чел., в Республике Башкортостан - 1184 чел. Метод сбора данных: анкетирование с помощью бумажных анкет и при помощи веб-ссылки на электронную анкету; платформа для опросов Simple Forms позволяла отслеживать поступающие анкеты и осуществлять контроль качества данных. Использовалась стратифицированная выборка по типу населенного пункта с квотированием по полу, возрасту, образованию и национальности респондентов, что обеспечивает валидность и репрезентативность выборки.

\section{Обзор литературы}

Теоретико-методологическая база исследования основывалась на работах Л. М. Дробижевой, в которых решаются методологические проблемы изучения этничности, этносоциальных процессов и формулируются подходы к решению сложных задач по преодолению этносоциального неравенства. Особую ценность имеют труды, посвященные изучению этнических процессов в национальных республиках Российской Федерации (Социальное неравенство ..., 2002; Дробижева, 2021).

Возможности интеграции этнических практик и традиций в экономику региона и «эффективного использования этнического потенциала» рассматриваются в работе Е. Ю. Перовой (Перова, 2016). В. Р. Маркарян на примере Кубани аргументирует значимость этнокультурного разнообразия и историко-культурного наследия народов, которые способствуют развитию туризма, росту уровня занятости и общей привлекательности региона (Маркарян, Мурашко, 2016). Влияние традиций народов и культур как один из главных факторов развития предпринимательства рассматривает Г. М. Аветов (Аветов, 2010). О. В. Печура выделяет такие этнические факторы экономики, как традиционная экономическая деятельность, предпринимательство и гуманитарное измерение экономики (образование, самореализация, творческие способности личности) (Печура, 2009).

В рамках рассматриваемой темы мы выделяем исследования, в которых рассматриваются вопросы влияния этнокультурного разнообразия на экономический рост. Ю. В. Попков и Е. А. Тюгашев отмечают примеры этнически гомогенных стран и этнически гетерогенных стран и регионов, которые экономически успешны (Попков, Тюгашев, 2018: 8-27). Этнические и национальные особенности моделей менеджмента рассматриваются К. В. Павловым. Однако под этническими особенностями автор понимает не столько национальную принадлежность, сколько общие исторические и психологические характерные черты народов и стран, которые определяют их экономическое поведение (Павлов, 2016).

Есть и другие мнения. Академик В. А. Тишков полагает, что социальная и экономическая культуры больше влияют на экономическое развитие, нежели этнические факторы. Личностные особенности имеют большее значение, чем особенности этноса и народа. Вместе с тем, он признает, что этническое самосознание повышает самооценку и мобилизует личностные ресурсы. Также ученый отмечает, что этническое и культурное многообразие оказывает положительное влияние на экономику, поскольку расширяет мировоззрение людей и обогащает социальную практику в разных областях (Тишков, 2005: 20-37).

Современным этносоциальным и этнокультурным проблемам, отдельным ее аспектам, особенностям их проявления в Республике Тыва, а также вопросам реализации национальной политики государства, посвящены целый ряд публикаций, позволяющих глубже понимать и оценивать социальнотрудовую и социокультурную сферы региона, в их числе работы Г. Ф. Балакиной, 3. В. Анайбан, С. П. Тюхтенева, А. Ч. Кылгыдай, Т. Ю. Гусакова, Ю. В. Попкова, Г. И. Поподько, А. Р. Салчака, Л. Б. Четыровой, И. С. Тарбастаевой и других авторов (Балакина, Анайбан, 1995; Балакина, 1996; Анайбан, Тюхтенева, 2008; Балакина, 2011; Балакина, Кылгыдай, 2015; Поподько, 2017; Тарбастаева, 2018; Гусаков, 2019; Четырова, 2019; Попков, 2020; Салчак, 2020).

Проблемам труда и занятости в Республике Тува в последние годы посвящены исследования авторского коллектива под руководством 3. Т. Голенковой. Социально-стратификационные процессы 
в Республике Тува анализируются и оцениваются в контексте неравенства в социально-трудовом пространстве региона. Социальное неравенство в трудовой сфере республики рассматривается как «дуальная» система организации труда и занятости населения (Голенкова, Самба, 2019; Социальностратификационные ..., 2020). Они также отмечают рост количества самозанятых в Республике Тыва, особенно в традиционных формах занятости среди населения (например, чабаны, табунщики, оленеводы и др.). Одновременно они вполне справедливо задаются вопросом: «учитываются ли эти формы занятости в официальной статистике» и еще раз подчеркивают, что причины безработицы и «отсутствие желания найти работу» (Социально-стратификационные ..., 2020: 13) среди населения может быть связано с национальными особенностями и традиционными ценностями населения республики.

Социально-экономические, трудовые, демографические, политические и социокультурные особенности этнических сообществ Республики Башкортостан, а также проблемы социального неравенства, дифференциации и другие вопросы, касающиеся этнических факторов поведения населения, рассмотрены в работах Дж. М. Гилязитдинова, Г. Т. Галиева, Р. М. Валиахметова, С. Х. Кадырова, Ф. Б. Латыповой, Р. И. Ирназарова, Ф. С. Файзуллина, Д. Г. Ягафаровой и др. (Галиев, Гилязитдинов, Латыпова, 1994; Валиахметов, Кадыров, Ягафарова, 2013: 62; Ирназаров, 1997, 2015; Файзуллин Ф., Файзуллин Т., 2014; Социальное неравенство ..., 2002: 300-319).

В докладе 2015 г. «Труд, занятость и человеческое развитие: Доклад о развитии человеческого потенциала в Республике Башкортостан» авторы анализируют вопросы рождаемости, семьи, образа и уровня жизни, миграции, экономической и трудовой активности в том числе через призму этнического состава населения (Труд, занятость ..., 2015: 256). В частности, выявлено, что малые и средние предприятия в области социального предпринимательства сравнительно чаще в республике Башкортостан возглавляют представители других этнических групп.

В целом мы отмечаем дефицит исследований в области занятости этнических групп, особенностей реализации их трудового потенциала, что частично объясняется отсутствием соответствующей статистики, сравнительных региональных исследований. Например, сравнение ситуации в Республике Тува (далее - РТ) и Республике Башкортостан (далее - РБ) еще не производилось, что определяет новизну данной работы.

\section{Общая характеристика сфер труда и занятости в республиках}

Доля населения трудоспособного возраста в республиках различается всего на один процент по данным за 2019 год (55,8\% в РБ, 54,8\% в РТ), однако доля занятых в экономике Башкортостана составляет $71,1 \%$ от численности населения трудоспособного возраста, а в Туве $-56,3 \%$ (это самый низкий показатель по стране) ${ }^{1}$. При этом уровень неформальной занятости по данным Росстата за 2019 год в РТ $(21,5 \%)$ был ниже, чем в РБ $(24,7 \%)^{2}$. Это, вероятнее всего, свидетельствует о том, что значительная доля сельского населения Республики Тува придерживается традиционного образа жизни и слабо взаимодействует с экономическими субъектами, институтами труда, занятости и социальной защиты населения.

Промышленность Республики Тува имеет преимущественно сырьевую направленность, приносящую при этом довольно значимый доход региону, но не обеспечивающую занятость населения. Так, по данным за 2019 г. добыча полезных ископаемых составила практически четверть валовой добавленной стоимости всех отраслей региональной экономики - 24,9\% (обрабатывающие производства $-0,7 \%)$. В Республике Башкортостан основу экономики региона составляет обрабатывающая промышленность, доля которой в региональном валовом продукте $35.1 \%$ (добыча полезных ископаемых для сравнения: $3,2 \%)^{3}$.

\footnotetext{
${ }^{1}$ Расчеты авторов по данным Росстата. Регионы России. Социально-экономические показатели. 2020: Стат. сб. / Росстат. M., 2020. 1242 с. [Электронный ресурс] // Федеральная служба государственной статистики. URL: https:// rosstat.gov.ru/folder/210/document/13204 (дата обращения: 15.09.2021).

${ }^{2}$ Обследование рабочей силы. 2020 [Электронный ресурс] // Федеральная служба государственной статистики. URL: https://rosstat.gov.ru/compendium/document/13265 (дата обращения: 15.09.2021).

${ }^{3}$ Там же. С. 496.
} 
Удельный вес городского населения РТ составляет около 53,1\%, сельского - 46,9\% (Социальностратификационные ..., 2020: 10). Тем не менее, доля сельского населения, с преобладанием коренного населения - тувинцев, низкая плотность автомобильных дорог с твердым покрытием (21 км / 1000 км² 310 км / $1000 \mathrm{kм}^{2}$ ) и другие факторы определяют сохранение в Республике Тува традиционных видов хозяйствования. При этом отсутствие налаженных каналов сбыта продукции традиционного животноводства в самой республике, а также в другие регионы России существенно сдерживает развитие как самой отрасли, так и региона и его рынка труда. В условиях низкой заработной платы, невысокой покупательной способности населения, сельское хозяйство развивается очень медленно (Самба, 2020).

Уровень трудовой занятости среди населения Республики Башкортостан выше, чем среди населения Республики Тува (таб. 1).

Несмотря на декларируемую приоритетность развития сельскохозяйственной отрасли в РТ, ее доля в структуре ВРП довольно мала и сокращается (5,4\% в 2019 г.) - в пять раз ниже доли добывающей промышленности. В сельском хозяйстве региона работает около $7,2 \%$ населения, в то время как в сфере добычи полезных ископаемых занято всего $3,8 \%$. Обрабатывающие производства развиты очень плохо и создают лишь 3,4\% ВРП региона. Подавляющая часть работающего населения концентрируется в секторе услуг, преимущественно в бюджетных отраслях здравоохранения, образования и предоставления социальных услуг (35,1\%). Бюджетные отрасли формируют около $43 \%$ валового регионального продукта. Такая структура занятости и ВРП являются свидетельством неразвитости экономики и высокой зависимости от федеральных трансфертов.

В Республике Башкортостан в сферах торговли (18,7\%), предоставлении прочих видов услуг $(15,9 \%)$ и обрабатывающих производствах $(15,4 \%)$ - наибольшая доля занятых. В добывающей промышленности всего 2,3\%. Однако специфика республики заключается в том, что Башкортостан занимает 3-е место среди субъектов РФ по абсолютному числу межрегиональных трудовых мигрантов по данным за 2019 год. И большая часть из них трудится в добывающей промышленности. А в процентном отношении к численности занятого населения региона РБ находится на 11-м месте среди всех регионов страны по числу временных трудовых мигрантов ${ }^{2}$. Бюджетные отрасли в РБ создают 21,7\% ВРП.

Таблица 1. Занятость населения по видам экономической деятельности в Республиках Тува и Башкортостан, 2019 г. ${ }^{2}$

Table 1. Employment of the population by type of economic activity in the Republics of Tuva and Bashkortostan, 2019.

\begin{tabular}{|c|c|c|c|c|c|c|}
\hline \multirow[t]{2}{*}{$\begin{array}{c}\text { Отрасли экономики (виды } \\
\text { экономической деятельности) }\end{array}$} & \multicolumn{3}{|c|}{$\begin{array}{c}\text { Распределение среднегодовой } \\
\text { численности занятых по видам } \\
\text { экономической деятельности } \\
\text { (в \% от общей численности } \\
\text { занятых) }\end{array}$} & \multicolumn{3}{|c|}{$\begin{array}{c}\text { Отраслевая структура видов } \\
\text { экономической деятельности } \\
\text { (в текущих основных ценах, } \\
\text { в \% к итогу) }\end{array}$} \\
\hline & $P \Phi$ & $P Б$ & $P T$ & $P \Phi$ & $P Б$ & $P T$ \\
\hline $\begin{array}{l}\text { Сельское, лесное хозяйство, охота, } \\
\text { рыболовство и рыбоводство }\end{array}$ & 6,7 & 7,1 & 7,2 & 4,3 & 6 & 5,4 \\
\hline Добыча полезных ископаемых & 1,6 & 2,3 & 3,8 & 14,8 & 3,2 & 24,9 \\
\hline Обрабатывающие производства & 14 & 15,4 & 3,4 & 18 & 35,1 & 0,7 \\
\hline
\end{tabular}

${ }^{1}$ O межрегиональной трудовой миграции в 2019 году [Электронный ресурс] // Федеральная служба государственной статистики. URL: https://rosstat.gov.ru/storage/mediabank/GhpJyhEX/mtm_2019.pdf (дата обращения: 15.09.2021).

${ }^{2}$ Регионы России. Социально-экономические показатели. 2020: Стат. сб. / Росстат. М., 2020. 1242 с. [Электронный ресурс] // Федеральная служба государственной статистики. URL: https://rosstat.gov.ru/folder/210/document/13204 (дата обращения: 15.09.2021). 


\begin{tabular}{|c|c|c|c|c|c|c|}
\hline \multirow[t]{2}{*}{$\begin{array}{c}\text { Отрасли экономики (виды } \\
\text { экономической деятельности) }\end{array}$} & \multicolumn{3}{|c|}{$\begin{array}{c}\text { Распределение среднегодовой } \\
\text { численности занятых по видам } \\
\text { экономической деятельности } \\
\text { (в \% от общей численности } \\
\text { занятых) }\end{array}$} & \multicolumn{3}{|c|}{$\begin{array}{c}\text { Отраслевая структура видов } \\
\text { экономической деятельности } \\
\text { (в текущих основных ценах, } \\
\text { в \% к итогу) }\end{array}$} \\
\hline & $P \Phi$ & $P Б$ & $P T$ & $P \Phi$ & $P Б$ & $P T$ \\
\hline $\begin{array}{l}\text { Обеспечение электрической энергией, } \\
\text { газом и паром; кондиционирование } \\
\text { воздуха }\end{array}$ & 2,3 & 2,3 & 2,1 & 3,1 & 2,6 & 2,2 \\
\hline $\begin{array}{l}\text { Водоснабжение; водоотведение, } \\
\text { организация сбора и утилизации } \\
\text { отходов, деятельность по ликвидации } \\
\text { загрязнений }\end{array}$ & 1 & 1 & 0,8 & 0,6 & 0,8 & 0,2 \\
\hline Строительство & 9 & 9,7 & 4,1 & 5,6 & 6,2 & 5,8 \\
\hline $\begin{array}{l}\text { Торговля оптовая и розничная; } \\
\text { ремонт автотранспортных средств и } \\
\text { мотоциклов }\end{array}$ & 19 & 18,7 & 13,6 & 15,8 & 13,7 & 6,4 \\
\hline Транспортировка и хранение & 7,6 & 6,3 & 3,5 & 7,6 & 6,1 & 1,8 \\
\hline $\begin{array}{l}\text { Деятельность гостиниц и предприятий } \\
\text { общественного питания }\end{array}$ & 2,5 & 2,8 & 2,2 & 1 & 1,1 & 0,6 \\
\hline $\begin{array}{l}\text { Деятельность в области информации } \\
\text { и связи }\end{array}$ & 2,1 & 1,7 & 1,2 & 3 & 2,2 & 2,1 \\
\hline Деятельность финансовая и страховая & & & & 0,5 & 0,3 & 0,2 \\
\hline $\begin{array}{l}\text { Деятельность по операциям с } \\
\text { недвижимым имуществом }\end{array}$ & 2,7 & 2,8 & 1,2 & 6,5 & 3,9 & 4,8 \\
\hline $\begin{array}{l}\text { Деятельность профессиональная, } \\
\text { научная и техническая }\end{array}$ & - & - & - & 4,4 & 4,3 & 0,7 \\
\hline $\begin{array}{l}\text { Деятельность административная } \\
\text { и сопутствующие дополнительные } \\
\text { услуги }\end{array}$ & - & - & - & 2,5 & 1,9 & 0,7 \\
\hline $\begin{array}{l}\text { Государственное управление и } \\
\text { обеспечение военной безопасности; } \\
\text { социальное обеспечение }\end{array}$ & - & - & - & 4,7 & 3,6 & 17 \\
\hline Образование & 7,6 & 7,4 & 23 & 3,1 & 3,8 & 12 \\
\hline $\begin{array}{l}\text { Деятельность в области } \\
\text { здравоохранения и социальных услуг }\end{array}$ & 6,2 & 6,7 & 12,1 & 3,9 & 4,2 & 12,7 \\
\hline $\begin{array}{l}\text { Деятельность в области культуры, } \\
\text { спорта, организации досуга и } \\
\text { развлечений }\end{array}$ & - & - & - & 0,9 & 0,5 & 1,5 \\
\hline
\end{tabular}




\begin{tabular}{|l|c|c|c|c|c|c|}
\hline \multirow{2}{*}{$\begin{array}{c}\text { Оттрасли экономики (виды } \\
\text { экономической деятельности) }\end{array}$} & \multicolumn{2}{|c|}{$\begin{array}{c}\text { Распределение среднегодовой } \\
\text { численности занятых по видам } \\
\text { экономической деятельности } \\
\text { (в \% от общей численности } \\
\text { занятых) }\end{array}$} & \multicolumn{2}{|c|}{$\begin{array}{c}\text { Отраслевая структура видов } \\
\text { экономической деятельности } \\
\text { (в текущих основных ценнах, } \\
\text { в \% к итогу) }\end{array}$} \\
\cline { 2 - 7 } & $P \Phi$ & $P 5$ & $P T$ & $P \Phi$ & $P 5$ & $P T$ \\
\hline Предоставление прочих видов услуг & 17,8 & 15,9 & 21,8 & 0,5 & 0,5 & 0,3 \\
\hline Итого & 100 & 100 & 100 & 100 & 100 & 100 \\
\hline
\end{tabular}

В Башкортостане более равномерное распределение численности занятых по отраслям экономики, чем в Туве. Почти половина занятых в Туве сконцентрирована в бюджетных сферах экономики. В РБ, по сравнению с РТ, гораздо больше занятых в обрабатывающей промышленности и меньше занятых в бюджетных отраслях экономики. В Башкортостане бо́льшая часть ВРП приходится на коммерческий сектор экономики. В Туве примерно половину ВРП производит коммерческий и примерно половину - бюджетный сектор.

\section{Этническая идентичность и занятость}

В целом по данным нашего исследования, оказалось, что в Республике Тыва 58,7\% респондентов имеют работу и $41,3 \%$ - не имеют (таб. 2) ${ }^{1}$. В Республике Башкортостан $76 \%$ респондентов работают и $24 \%$ - не работают. При этом, по состоянию здоровья не работают $8 \%$ опрошенных жителей РБ и $10 \%$ - жителей РТ. 22\% респондентов из Башкортостана и 8\% респондентов из Тувы ответили, что «не работают, так как обеспечены всем необходимым».

Не могут найти работу по специальности 5\% опрошенных РБ и 7\% опрошенных местных жителей РТ; работу с хорошей зарплатой не могут найти $10 \%$ респондентов РБ и $12 \%$ респондентов РТ; работу с подходящим графиком - 12\% респондентов из РБ и 11\% - из РТ. Остальные респонденты отметили другие причины незанятости или затруднились ответить.

Таблица 2. Трудовой статус в зависимости от этнической принадлежности по республикам Башкортостан и Тува, \% от всех ответивших

Table 2. Labor status depending on ethnicity in the Republics of Bashkortostan and Tuva, \% of all respondents.

\begin{tabular}{|c|c|c|c|c|}
\hline Национальность & $\begin{array}{c}\text { Имею постоянную } \\
\text { работу }\end{array}$ & $\begin{array}{c}\text { Имею временную } \\
\text { работу }\end{array}$ & Не работаю & Всего по строке \\
\hline & \multicolumn{4}{|c|}{ Республика Башкортостан } \\
\hline Башкир (-ка) & 60,0 & 16,1 & 23,9 & 100,0 \\
\hline Русский (-ая) & 62,5 & 12,7 & 24,8 & 100,0 \\
\hline Татарин (-ка) & 57,3 & 15,6 & 27,1 & 100,0 \\
\hline Другая & 76,1 & 6,5 & 17,4 & 100,0 \\
\hline \multirow[t]{2}{*}{ Всего } & 60,9 & 14,2 & 24,9 & 100,0 \\
\hline & \multicolumn{4}{|c|}{ Республика Тыва } \\
\hline Тувинец (-ка) & 44,7 & 7,5 & 47,8 & 100,0 \\
\hline Русский (-ая) & 55,5 & 5,9 & 38,6 & 100,0 \\
\hline Другая & 55,3 & 10,6 & 34,1 & 100,0 \\
\hline Всего & 46,7 & 7,6 & 45,7 & 100,0 \\
\hline
\end{tabular}

${ }^{1}$ В этой и последующих таблицах в группе этносов не расшифровываются «другая», т. к. их численность значительно меньше, чем указанных. 
Причины отсутствия работы у неработающего населения Тувы и Башкортостана понимаются опрошенными по-разному. Среди населения Башкортостана в два раза меньше доля тех, кто ответил, что не работает по причине самозанятости, чем среди населения Тувы (5\% против $10 \%$ соответственно).

Теперь рассмотрим, как соотносят этническую принадлежность с вопросами занятости и перспектив трудоустройства наши респонденты. Этот ракурс важен для понимания степени сохранения или, наоборот, исчезновения/нивелирования предрасположенности отдельных этнических групп к определенным видам экономической деятельности. Есть еще одна немаловажная сторона поставленного вопроса, ответ на который позволил бы прояснить, насколько этническая идентификация человека связана с его трудоустройством и устойчивостью на рынке труда.

Временно трудозанятые жители Башкортостана и Тувы гораздо меньше ценят этническую принадлежность в сравнении с респондентами, имеющими постоянную работу и неработающими опрошенными жителями двух республик (табл. 3) ${ }^{1}$. Процент ответов по категориям «очень важна» и «скорее важна» для постоянных работников из Башкортостана составляет 37,3\%, а для временных работников из данной республики $-24,4 \%$. По Республике Тува сумма процентов по ответам «очень важна» и «важна» для постоянных работников оставляет $65,9 \%$, и сумма ответов по данным категориям для временных работников $-51,2 \%$. В то же время среди временных работников из обеих республик процент тех, кто ответил, что этническая принадлежность «скорее не важна» и «совершенно не важна» больше, чем среди постоянных работников. В данном случае важность этничности снижается заметно, если человек работает в условиях неустойчивой занятости. При этом жители Тувы больше ценят этническую принадлежность в целом, чем жители Башкортостана.

Таблица 3. Распределение трудовых позиций в зависимости от оценки степени важности этнической принадлежности по республикам Башкортостан и Тува, \% от всех ответивших Table 3. Distribution of labor statuses depending on the degree of significance of ethnicity in the Republics of Bashkortostan and Tuva, \% of all respondents.

\begin{tabular}{|c|c|c|c|c|c|c|c|}
\hline Трудовой статус & $\begin{array}{l}\text { Очень } \\
\text { важна }\end{array}$ & $\begin{array}{c}\text { Скорее } \\
\text { важна, чем } \\
\text { не важна }\end{array}$ & $\begin{array}{c}\text { Не думал об этом, } \\
\text { мне все равно / И } \\
\text { важна, и не важна } \\
\text { примерно равно }\end{array}$ & $\begin{array}{c}\text { Скорее не } \\
\text { важна }\end{array}$ & $\begin{array}{c}\text { Совершенно } \\
\text { не важна }\end{array}$ & $\begin{array}{c}\text { Затрудняюсь } \\
\text { ответить }\end{array}$ & $\begin{array}{l}\text { Всего } \\
\text { по } \\
\text { строке }\end{array}$ \\
\hline & \multicolumn{7}{|c|}{ Республика Башкортостан } \\
\hline $\begin{array}{l}\text { Имею } \\
\text { постоянную } \\
\text { работу }\end{array}$ & 13,9 & 23,4 & 27,1 & 12,3 & 18,6 & 4,7 & 100 \\
\hline $\begin{array}{l}\text { Имею } \\
\text { временную } \\
\text { работу }\end{array}$ & 13,7 & 10,7 & 26,7 & 14,9 & 28,0 & 6,0 & 100 \\
\hline Не работаю & 12,9 & 24,1 & 23,1 & 12,2 & 23,6 & 4,1 & 100 \\
\hline \multirow[t]{2}{*}{ Всего } & 13,6 & 21,8 & 26,0 & 12,7 & 21,2 & 4,7 & 100 \\
\hline & \multicolumn{7}{|c|}{ Республика Тыва } \\
\hline $\begin{array}{l}\text { Имею } \\
\text { постоянную } \\
\text { работу }\end{array}$ & 48,6 & 17,3 & 13,9 & 7,0 & 8,7 & 4,5 & 100 \\
\hline $\begin{array}{l}\text { Имею } \\
\text { временную } \\
\text { работу }\end{array}$ & 31,0 & 20,2 & 14,3 & 8,3 & 19,1 & 7,1 & 100 \\
\hline Не работаю & 37,4 & 22,8 & 13,6 & 6,7 & 11,5 & 8,0 & 100 \\
\hline Всего & 42,2 & 20,1 & 13,7 & 7,0 & 10,7 & 6,3 & 100 \\
\hline
\end{tabular}

${ }^{1}$ Вопрос «Насколько для Вас важна Ваша национальность, национальная принадлежность?» 
Субъективная оценка вероятности потерять свою работу или страх потерять свою работу не очень сильно взаимосвязаны с этнической самоидентификацией в обеих рассматриваемых республиках (табл. 4). В целом жители Башкортостана больше опасаются потерять свою работу. А среди жителей Тувы больше доля респондентов, которые затруднились ответить, т. е. находились в пограничном состоянии своей оценки вероятности или страха потерять работу.

Таблица 4. Распределение ответов на вопрос «Как Вы думаете, можете ли Вы / боитесь ли Вы потерять источник своего дохода (работу или собственное дело)?» в зависимости от этнической принадлежности по республикам Башкортостан и Тува, \% от всех ответивших

Table 4. Distribution of answers to the question "Do you think you may lose / are afraid of losing the source of your income (job or your own business)?” depending on ethnicity in the Republics of Bashkortostan and Tuva, \% of all respondents.

\begin{tabular}{|c|c|c|c|c|}
\hline Национальность & $\begin{array}{c}\text { Нет, думаю, это } \\
\text { маловероятно }\end{array}$ & $\begin{array}{c}\text { Да, это вполне } \\
\text { вероятно }\end{array}$ & $\begin{array}{c}\text { Затрудняюсь } \\
\text { ответить }\end{array}$ & $\begin{array}{l}\text { Всего по } \\
\text { строке }\end{array}$ \\
\hline & \multicolumn{4}{|c|}{ Республика Башкортостан } \\
\hline Башкир (-ка) & 53,3 & 32,2 & 14,5 & 100 \\
\hline Русский (-ая) & 55,5 & 33,3 & 11,2 & 100 \\
\hline Татарин (-ка) & 51,0 & 43,1 & 5,9 & 100 \\
\hline Другая & 55,2 & 39,5 & 5,3 & 100 \\
\hline \multirow[t]{2}{*}{ Всего } & 53,6 & 35,9 & 10,5 & 100 \\
\hline & \multicolumn{4}{|c|}{ Республика Тыва } \\
\hline Тувинец (-ка) & 50,5 & 27,7 & 21,8 & 100 \\
\hline Русский (-ая) & 45,2 & 27,4 & 27,4 & 100 \\
\hline Другая & 46,4 & 21,4 & 32,2 & 100 \\
\hline Всего & 49,4 & 27,0 & 23,6 & 100 \\
\hline
\end{tabular}

Жители Тувы, которые уверены в том, что будут работать на своей нынешней трудовой позиции, выше ценят свою этническую принадлежность, чем те опрошенные местные жители, которые заявили о возможной потере своей работы (табл. 5). Среди жителей Башкортостана картина обратная: ценят свою этническую принадлежность в большей мере респонденты, которые боятся потерять свою работу или свое дело. Это говорит о том, что связь ценности своей этнической идентификации с устойчивостью на рынке труда в Башкортостане слабее, чем в Туве.

Таблица 5. Распределение ответов на вопрос «Как Вы думаете, можете ли Вы / боитесь ли Вы потерять источник своего дохода (работу или собственное дело)?» в зависимости от степени важности этнической принадлежности по республикам Башкортостан и Тува, \% от всех ответивших

Table 5. Distribution of answers to the question "Do you think you may lose / are afraid of losing the source of your income (job or your own business)?” depending on the degree of significance of ethnicity in the Republics of Bashkortostan and Tuva, \% of all respondents

\begin{tabular}{|c|c|c|c|c|c|c|c|}
\hline $\begin{array}{c}\text { Вероятность } \\
\text { потерять работу }\end{array}$ & $\begin{array}{l}\text { Очень } \\
\text { важна }\end{array}$ & $\begin{array}{l}\text { Скорее } \\
\text { важна, } \\
\text { чем не } \\
\text { важна }\end{array}$ & $\begin{array}{c}\text { Не думал об } \\
\text { этом, мне все } \\
\text { равно/ И важна, } \\
\text { и не важна } \\
\text { примерно равно }\end{array}$ & $\begin{array}{c}\text { Скорее не } \\
\text { важна }\end{array}$ & $\begin{array}{c}\text { Совершенно } \\
\text { не важна }\end{array}$ & $\begin{array}{c}\text { Затрудняюсь } \\
\text { ответить }\end{array}$ & $\begin{array}{l}\text { Всего по } \\
\text { строке }\end{array}$ \\
\hline & \multicolumn{7}{|c|}{ Республика Башкортостан } \\
\hline $\begin{array}{l}\text { Нет, думаю, это } \\
\text { маловероятно }\end{array}$ & 11,5 & 20,8 & 29,3 & 11,1 & 22,9 & 4,4 & 100 \\
\hline
\end{tabular}




\begin{tabular}{|c|c|c|c|c|c|c|c|}
\hline $\begin{array}{c}\text { Вероятность } \\
\text { потерять работу }\end{array}$ & $\begin{array}{l}\text { Очень } \\
\text { важна }\end{array}$ & $\begin{array}{l}\text { Скорее } \\
\text { важна, } \\
\text { чем не } \\
\text { важна }\end{array}$ & $\begin{array}{c}\text { Не думал об } \\
\text { этом, мне все } \\
\text { равно/ И важна, } \\
\text { и не важна } \\
\text { примерно равно }\end{array}$ & $\begin{array}{c}\text { Скорее не } \\
\text { важна }\end{array}$ & $\begin{array}{c}\text { Совершенно } \\
\text { не важна }\end{array}$ & $\begin{array}{c}\text { Затрудняюсь } \\
\text { ответить }\end{array}$ & $\begin{array}{l}\text { Всего по } \\
\text { строке }\end{array}$ \\
\hline & \multicolumn{7}{|c|}{ Республика Башкортостан } \\
\hline $\begin{array}{l}\text { Да, это вполне } \\
\text { вероятно }\end{array}$ & 17,9 & 23,2 & 26,3 & 16,3 & 12,8 & 3,5 & 100 \\
\hline $\begin{array}{l}\text { Затрудняюсь } \\
\text { ответить }\end{array}$ & 11,8 & 15,1 & 17,2 & 9,7 & 33,3 & 12,9 & 100 \\
\hline \multirow[t]{2}{*}{ Всего } & 13,8 & 21,0 & 27,0 & 12,8 & 20,4 & 5,0 & 100 \\
\hline & \multicolumn{7}{|c|}{ Республика Тыва } \\
\hline $\begin{array}{l}\text { Нет, думаю, это } \\
\text { маловероятно }\end{array}$ & 48,8 & 20,6 & 11,5 & 6,9 & 6,9 & 5,3 & 100 \\
\hline $\begin{array}{l}\text { Да, это вполне } \\
\text { вероятно }\end{array}$ & 40,4 & 18,1 & 17,5 & 7,8 & 12,0 & 4,2 & 100 \\
\hline $\begin{array}{l}\text { Затрудняюсь } \\
\text { ответить }\end{array}$ & 47,0 & 11,3 & 15,2 & 7,3 & 14,6 & 4,6 & 100 \\
\hline Всего & 46,2 & 17,7 & 14,0 & 7,2 & 10,0 & 4,9 & 100 \\
\hline
\end{tabular}

Жители Тувы чаще жителей Башкортостана считают, что этническая принадлежность оказывает влияние на возможность получить качественное образование, медицинскую помощь, хорошо оплачиваемую работу, а также открыть и вести свое дело (табл. 6).

Среди этнических сообществ двух республик значимость этнической принадлежности в получении хорошо оплачиваемой работы отмечают в сравнительно большей мере русские из Башкортостана, а также тувинцы и русские из Тувы. Башкиры в меньшей степени полагают, что этническая принадлежность влияет на возможность получить хорошо оплачиваемую работу. Респонденты считают, что этническая принадлежность влияет на возможность для открытия своего дела. На это больше указывают тувинцы из Тувы и русские из Республики Башкортостан. Русские, живущие в Башкортостане, также гораздо чаще представителей других этносов из обеих республик указывают на высокую степень влияния этнической принадлежности на возможность занимать высокие должности в органах власти и управления.

Таблица 6. Распределение ответов на вопрос «Как Вы считаете, влияет ли национальная принадлежность человека на следующие стороны жизни и возможности в Вашей республике?» в зависимости от этнической принадлежности по республикам Башкортостан и Тува

Table 6. Distribution of answers to the question "In your opinion, does a person's nationality affect the following aspects of life and opportunities in your republic?” depending on ethnicity in the Republics of Bashkortostan and Tuva

\begin{tabular}{|c|c|c|c|c|c|c|c|c|c|}
\hline Возможности & 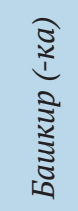 & 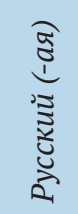 & 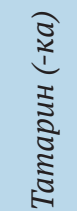 & 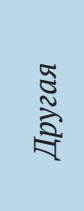 & 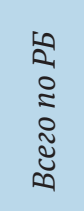 & 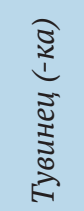 & 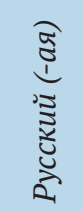 & 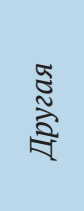 & $\begin{array}{c}5 \\
\vdots \\
\vdots \\
0 \\
\tilde{U} \\
\infty\end{array}$ \\
\hline $\begin{array}{l}\text { На возможность получить качественное } \\
\text { образование }\end{array}$ & 2,55 & 2,43 & 2,5 & 2,43 & 2,48 & 2,33 & 2,34 & 1,99 & 2,27 \\
\hline $\begin{array}{l}\text { На возможность получить качественную } \\
\text { медицинскую помощь }\end{array}$ & 2,72 & 2,58 & 2,59 & 2,48 & 2,62 & 2,34 & 2,4 & 2,09 & 2,29 \\
\hline
\end{tabular}




\begin{tabular}{|l|c|c|c|c|c|c|c|c|c|}
\hline $\begin{array}{l}\text { На возможность получить хорошо } \\
\text { оплачиваемую работу }\end{array}$ & 2,43 & 2,26 & 2,39 & 2,32 & 2,35 & 2,24 & 2,25 & 2,01 & 2,2 \\
\hline $\begin{array}{l}\text { На возможность открыть и вести свое } \\
\text { дело (бизнес) }\end{array}$ & 2,51 & 2,41 & 2,49 & 2,21 & 2,45 & 2,31 & 2,45 & 2,24 & 2,29 \\
\hline $\begin{array}{l}\text { На возможность занимать высокие } \\
\text { должности в органах власти и } \\
\text { управления }\end{array}$ & 2,34 & 2,14 & 2,32 & 1,9 & 2,24 & 2,3 & 2,31 & 2,29 & 2,28 \\
\hline
\end{tabular}

Прим.: средние оценки: 1 - влияет значительно, 2 - влияет не значительно, 3 - не влияет.

Респонденты из Башкортостана больше удовлетворены перспективами карьеры, повышения образования и квалификации, чем респонденты из Тувы (табл. 7). Среди жителей Республики Башкортостан русские больше всех удовлетворены перспективами своей карьеры и служебного роста, а башкиры - меньше всех. При этом башкиры также меньше остальных представителей этносов своего региона проживания удовлетворены возможностями для учебы и повышения квалификации.

В Республике Тува, в свою очередь, тувинцы больше удовлетворены перспективами карьерного роста, чем русские. В оценках уровня удовлетворенности возможностями для учебы и повышения квалификации тувинцы и русские из Тувы солидарны.

Таблица 7. Распределение ответов на вопрос «Насколько Вы удовлетворены в настоящее время следующими сторонами своей жизни?» в зависимости от этнической принадлежности по республикам Башкортостан и Тува

Table 7. Distribution of answers to the question "How satisfied are you with the following aspects of your life at the present time?" depending on ethnicity in the Republics of Bashkortostan and Tuva

\begin{tabular}{|c|c|c|c|c|c|c|c|c|c|}
\hline Стороны жизни & 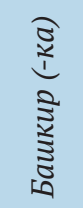 &  & 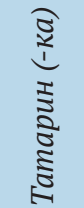 & 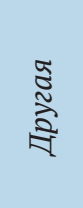 & 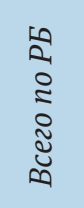 & 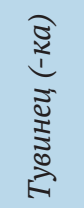 & 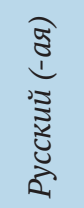 & 胥 & $\begin{array}{l}\vdots \\
\vdots \\
\vdots \\
\tilde{\Xi} \\
\infty \\
\infty\end{array}$ \\
\hline Материальным положением & 1,95 & 2,03 & 2,11 & 1,98 & 2,04 & 2,21 & 2,28 & 2,05 & 2,16 \\
\hline Жилищными условиями & 1,67 & 1,63 & 1,70 & 1,59 & 1,67 & 2,02 & 1,94 & 1,84 & 1,97 \\
\hline $\begin{array}{l}\text { Возможностями для учебы, } \\
\text { повышения квалификации }\end{array}$ & 1,86 & 1,80 & 1,81 & 1,76 & 1,82 & 2,10 & 2,11 & 2,03 & 2,05 \\
\hline $\begin{array}{l}\text { Перспективами карьеры, } \\
\text { служебного роста }\end{array}$ & 2,03 & 1,92 & 1,96 & 1,81 & 1,96 & 2,18 & 2,25 & 2,10 & 2,17 \\
\hline $\begin{array}{l}\text { Возможностями для поддержания } \\
\text { своего здоровья }\end{array}$ & 1,82 & 1,95 & 2,03 & 1,79 & 1,94 & 2,14 & 2,24 & 1,95 & 2,12 \\
\hline $\begin{array}{l}\text { Возможностями для отдыха, } \\
\text { развлечений }\end{array}$ & 1,98 & 2,03 & 2,06 & 1,76 & 2,02 & 2,24 & 2,32 & 2,22 & 2,23 \\
\hline Своей жизнью в целом & 1,56 & 1,61 & 1,67 & 1,61 & 1,62 & 1,88 & 1,94 & 1,72 & 1,84 \\
\hline
\end{tabular}

Прим.: средние оценки: 1 - вполне удовлетворен, 2 - частично удовлетворен, 3 - не удовлетворен.

Для выявления этносоциальных особенностей занятости населения в республиках Тува и Башкортостан нами были отобраны два ключевых индикатора - этническая идентичность и ценность национальной принадлежности. Выяснилось, что жители Тувы сравнительно больше ценят этническую принадлежность в целом, чем жители Башкортостана. Ценность и важность этнической принадлежности для жителей Тувы и Башкортостана падает заметно, если их трудовая занятость осуществляется в условиях неустойчивой занятости (временной работы). Ценность этнической при- 
надлежности связана с уверенностью в устойчивости своей позиции на рынке труда. Жители Тувы, уверенные в том, что не потеряют свою работу, чаще заявляют о важности своей национальности, чем респонденты из Башкортостана.

Этническая принадлежность, по мнению опрошенных жителей двух республик, влияет на возможности расширения образовательных стратегий, успешного трудоустройства и хорошо оплачиваемой работы, а также на возможность открыть и вести свое дело. По мнению респондентов, возможности для карьерного роста и повышения своей квалификации сравнительно выше в Республике Башкортостан, чем в Республике Тува. При этом башкиры меньше удовлетворены возможностями развития в трудовой сфере, чем представители других национальностей Башкортостана. Тувинцы больше довольны возможностями карьерного роста, чем русские Республики Тува, однако здесь и русские, и тувинцы одинаково оценивают перспективы получения образования и повышения своей квалификации.

\section{Заключение}

Сравнительный анализ этносоциальных особенностей занятости в двух республиках Российской Федерации - Башкортостане и Туве - показал следующее. Несмотря на существенные различия по природно-климатическим условиям, географическому положению, структуре экономики, темпам модернизации и человеческому потенциалу в обоих республиках есть общее - ярко выраженные этнические особенности занятости населения. Этническая принадлежность и другие этнодифференцирующие признаки продолжают влиять на целый ряд возможностей населения, включая установки на определенные виды занятости.

Разумеется, этнический состав населения и предрасположенность отдельных этнических общностей к отдельным видам экономической деятельности не являются определяющими факторами социально экономического развития республик. Наиболее значимыми отраслями экономики Башкортостана по доле ВРП и занятости являются обрабатывающие производства, торговля и сектор услуг. В Республике Тува большая часть занятых работает в сферах образования, здравоохранения, торговле и прочих услугах, при этом бюджетные отрасли формируют значимую часть регионального ВРП. В Башкортостане уровень занятости выше, отмечается более равномерное распределение численности работников по отраслям экономики, чем в Туве. Уровень занятости в Туве остается низким, значительная часть занятых находится в неформальном секторе экономики, масштабы которой, на наш взгляд, более существенны. Эти показатели свидетельствуют о неразвитости экономики и высокой зависимости Тувы от федеральной помощи.

Результаты опроса общественного мнения населения республик дополняют объективные показатели статистики. Возможности для получения хорошей работы и повышения своего образования и квалификации выше в Башкортостане, чем в Туве, по мнению опрошенных жителей республик, что соотносится с общими показателями занятости в данных регионах.

Уверенность жителей Тувы в своей трудовой позиции связана с важностью и ценностью своей этнической принадлежности. Чем больше они ее ценят, тем более уверенно чувствуют себя на рынке труда. Это, скорее всего, связано с тем, что процессы трудоустройства в Туве зависят также от земляческих, этнических, родственных предпочтений работодателей. Известно, что в менее модернизированных обществах, в которых преобладают традиционные виды экономической деятельности, принадлежность к сообществу по упомянутым признакам играет большую роль. Например, ученые отмечают, что существует разница в особенностях структуры рынка труда тувинцев и русских. Русские Тувы имеют более высокий уровень образования, и среди них больше занятых, работающих в отраслях экономики, которые требуют высокотехнологичных навыков. Тувинцы менее образованы и менее конкурентоспособны за пределами республики. При этом тувинцы сравнительно больше русских уверены в своем будущем в родной республике (Балакина, Кылгыдай, 2015: 102-103).

Возможности для карьерного роста и повышения своей квалификации, по мнению респондентов, выше в Башкортостане, чем в Туве. Это связано, с одной стороны, с общим уровнем развития экономики и сферы труда в республиках. С другой стороны, сама специфика трудовой занятости в регионах определяет такую особенность. В Туве значительная часть населения заняты в неформальном секторе экономики, что предполагает самостоятельный поиск ресурсов и заработка. Тува более изолирована от других регионов страны в транспортном и социальном плане, что затрудняет социально-трудовую и образовательную мобильность населения республики. В Башкортостане уровень занятости выше, и 
к тому же много межрегиональных трудовых мигрантов, которые уезжают на работу в другие регионы России. Также в республике выше общая социально-трудовая и образовательная мобильность местного населения как внутри региона, так и за его пределами.

Результаты исследования позволяют сформулировать некоторые рекомендации органам государственной власти и управления исследуемых республик. В совокупности они сводятся к учету не только материальных и финансовых ресурсов, но и неэкономических факторов развития региона. В их числе социокультурные и этнические особенности занятости населения, умелое и активное использование которых становится одним из «внутренних» источников социально-экономического развития республик.

\section{СПИСОК ЛИТЕРАТУРЫ}

Аветов, Г. М. (2010) Влияние этнического фактора на формирование российской системы предпринимательства: основные аспекты // Экономические науки. № 72. С. 51-55.

Анайбан, 3. В., Тюхтенева, С. П. (2008) Этнокультурная адаптация населения Южной Сибири (современный период). М. : Институт востоковедения РАН. 217 с.

Балакина, Г. Ф. (1996) Экономика региона в период реформ: Республика Тыва. Новосибирск : Наука, Сибирская издательская фирма РАН. 96 с.

Балакина, Г. Ф. (2011) Стратегии развития Республики Тува как депрессивного региона // Экономическое возрождение России. № 4 (30). С. 99-107.

Балакина, Г. Ф., Анайбан, З. В. (1995) Современная Тува: социокультурные и этнические процессы. Новосибирск : Наука, Сибирская издательская фирма РАН. 137 с.

Балакина, Г. Ф., Кылгыдай, А. Ч. (2015) Этнорегиональные модели адаптации к рынку труда в Туве. Кызыл : ТувИКОПР СО РАН. 160 с.

Валиахметов, Р. М., Кадыров, С. Х., Ягафарова, Д. Г. (2013) Экономический и социальный капитал башкирского народа // Вестник Российского университета дружбы народов. Серия: Социология. № 2. С. 51-63.

Галиев, Г. Т., Гилязитдинов, Дж. М., Латыпова, Ф. Б. (1994) Этническая стратификация и ее влияние на межнациональные отношения. Уфа : Салаватская городская типография Минпечати Республики Башкортостан. 40 с.

Голенкова, 3. Т., Самба, А. Д.-Б. (2019) Прошлое, настоящее и будущее социального пространства в регионе // Информационно-аналитический бюллетень Института социологии ФНИСЦ РАН. № 3. Особенности социальной стратификации в Республике Тыва. С. 5-17. DOI: https://doi.org/10.19181/inab.2019.3.1

Гусаков, Т. Ю. (2019) Многоукладность современного этнического региона России: архаизация, аграризация и миграции (на примере Республики Тыва) // Крестьяноведение. Т. 4. № 4. С. 76-95.DOI: https://doi.org/10.22394/25001809-2019-4-4-76-95

Дробижева, Л. М. (2021) Опыт 1990-х гг. и управление культурным многообразием // Социологические исследования. № 8. С. 51-61. DOI: https://doi.org/10.31857/S013216250015254-2

Ирназаров, Р. И. (1997) Равенство этносов в Республике Башкортостан. Уфа : Гилем. 160 с.

Ирназаров, Р. И. (2015) К вопросу о дифференциации этносов в Башкортостане // Социологические исследования. № 8. С. 56-60.

Лапин, Н. И. (2014) Проблемы формирования концепции и человеческих измерений стратегии поэтапной модернизации России и ее регионов // Социологические исследования. № 7. С. 8-19.

Маркарян, В. Р., Мурашко С. Ф. (2016) Этнос и этническая идентичность как ресурс социально-экономического развития региона // Этносоциум и межнациональная культура. № 6 (96). С. 60-68.

Павлов, К. В. (2016) Этноменеджмент как составная часть этноэкономики // Вестник Института экономических исследований. № 2 (2). С. 13-28.

Перова, Е. Ю. (2016) Этническая экономика как направление повышения эффективности использования социальных ресурсов региона // Известия Байкальского государственного университета. Т. 26. № 5. С. 705-712.

Печура, О. В. (2009) Этнический фактор в развитии экономики региона // Известия Уральского государственного экономического университета. № 2 (24). С. 138-143.

Попков, Ю. В. (2020) Современная российская национальная политика: концептуально-целевые основы и опыт реализации (на примере Тувы) // Новые исследования Тувы. № 3. С. 253-268. DOI: www.doi.org/10.25178/ nit.2020.3.18

Попков, Ю. В., Тюгашев Е. А. (2018) Этнокультура и экономика: синергия возможностей // ЭКО. № 5. С. 8-27. 
Поподько, Г. И. (2017) Пути преодоления неравенства социально-экономического развития отсталых регионов (на примере Республики Тыва) // Региональная экономика: теория и практика. № 2. C. 315-328. DOI: https://doi. org/10.24891/re.15.2.315

Салчак, А. Р. (2020) Анализ состояния рынка труда Республики Тыва // Экономика: вчера, сегодня, завтра. Т. 10. № 7A. C. 191-200.

Самба, А. Д. (2020) Основные изменения в социально-трудовом пространстве Республики Тыва // Экономика и управление: научно-практический журнал. № 1. С. 47-50. DOI: https://doi.org/10.34773/EU.2020.1.12

Социальное неравенство этнических групп: представления и реальность (2002) / авт. проекта и отв. ред. Л. М. Дробижева. М. : Academia. 480 с.

Социально-стратификационные процессы в Республике Тыва (2020) / 3. Т. Голенкова и др. М.: ФНИСЦ РАН. 112 c. DOI: https://doi.org/10.19181/monogr.978-5-89697-332-4.2020

Тарбастаева, И. С. (2018) Тува превращается в моноэтничный регион: риски и перспективы // ЭКО. № 5 (527). C. $65-80$.

Тишков, В. А. (2005) Рыночная экономика и этническая среда // Общество и экономика. № 12. С. 20-37.

Труд, занятость и человеческое развитие: Доклад о развитии человеческого потенциала в республике Башкортостан (2015) / Р. М. Валиахметов, А. М. Аллаярова, М. В. Артамонова и др. Уфа : Восточная печать. 360 с.

Файзуллин, Ф. С., Файзуллин, Т. Ф. (2014) Региональные особенности социального развития этнических общностей // Вестник Академии наук Республики Башкортостан. Т. 19. № 3. С. 67-75.

Четырова, Л. Б. (2019) Трансформация труда в постсовременном мире: ресурсы интеграции этнической трудовой культуры (на примере Тувы и Калмыкии) // Новые исследования Тувы. № 3. C. 77-88. DOI: https://doi. org/10.25178/nit.2019.3.7

Дата поступления: 12.10.2021 2.

\section{REFERENCES}

Avetov, G. M. (2010) Vliianie etnicheskogo faktora na formirovanie rossiiskoi sistemy predprinimatel'stva: osnovnye aspekty [The influence of the ethnic factor on the formation of Russian entrepreneurship system: Main aspects]. Ekonomicheskie nauki, no. 72, pp. 51-55. (In Russ.).

Anaiban, Z. V. and Tiukhteneva, S. P. (2008) Etnokul'turnaia adaptatsiia naseleniia Iuzhnoi Sibiri (sovremennyi period) [Ethnocultural adaptation of the population of Southern Siberia in the contemporary period]. Moscow, Institute of Oriental Studies of the RAS. 217 p. (In Russ.).

Balakina, G. F. (1996) Ekonomika regiona v period reform: Respublika Tyva. [The region's economy in the reform period: The Republic of Tuva]. Novosibirsk, Nauka Publ. 96 p. (In Russ.).

Balakina, G. F. (2011) Strategii razvitiia Respubliki Tuva kak depressivnogo regiona [Development strategies of the Republic of Tuva as a depressed region]. Ekonomicheskoe vozrozhdenie Rossii, no. 4 (30), pp. 99-107. (In Russ.).

Balakina, G. F. and Anaiban, Z. V. (1995) Sovremennaia Tuva: sotsiokul'turnye i etnicheskie protsessy [Contemporary Tuva: Socio-cultural and ethnic processes]. Novosibirsk, Nauka Publ. 137 p. (In Russ.).

Balakina, G. F. and Kylgydai, A. Ch. (2015) Etnoregional'nye modeli adaptatsii k rynku truda v Tuve [Ethno-regional models of adaptation to the labour market in Tuva]. Kyzyl, Tuvinian Institute for Exploration of Natural Resources of the Siberian Branch of the RAS. 160 p. (In Russ.).

Valiakhmetov, R. M., Kadyrov, S. Kh. and Yagafarova, D. G. (2013) Ekonomicheskii i sotsial'nyi kapital bashkirskogo naroda [Economic and social capital of the Bashkir people]. RUDN Journal of Sociology, no. 2, pp. 51-63. (In Russ.).

Galiev, G. T., Giliazitdinov, Dzh. M. and Latypova, F. B. (1994) Etnicheskaia stratifikatsiia i ee vliianie na mezhnatsional'nye otnosheniia [Ethnic stratification and its influence on interethnic relations]. Ufa, Salavat City Printing House of the Ministry of Printing of the Republic of Bashkortostan. 40 p. (In Russ.).

Golenkova, Z. T. and Samba, A. D.-B. (2019) Proshloe, nastoiashchee i budushchee sotsial'nogo prostranstva v regione [The past, present and future of social space in the region]. Informatsionno-analiticheskii biulleten' Instituta sotsiologii FNISTs RAN, no. 3. Osobennosti sotsial'noi stratifikatsii v Respublike Tyva [Features of social stratification in the Republic of Tuva], pp. 5-17. (In Russ.). DOI: https://doi.org/10.19181/inab.2019.3.1

Gusakov, T. Yu. (2019) Mnogoukladnost' sovremennogo etnicheskogo regiona Rossii: arkhaizatsiia, agrarizatsiia i migratsii (na primere Respubliki Tyva) [The multistructure of the contemporary ethnic region in Russia: Archaization, agrarianization and migration (The case of the Republic of Tuva)]. Russian Peasant Studies, vol. 4, no. 4, pp. 76-95. (In Russ.). DOI: https://doi.org/10.22394/2500-1809-2019-4-4-76-95 
Drobizheva, L. M. (2021) Opyt 1990-kh gg. i upravlenie kul'turnym mnogoobraziem [1990s experience and cultural diversity management]. Sotsiologicheskie issledovaniia, no. 8, pp. 51-61. (In Russ.). DOI: https://doi.org/10.31857/ S013216250015254-2

Irnazarov, R. I. (1997) Ravenstvo etnosov v Respublike Bashkortostan [Equality of ethnic groups in the Republic of Bashkortostan]. Ufa, Gilem Publ. 160 p. (In Russ.).

Irnazarov, R. I. (2015) K voprosu o differentsiatsii etnosovv Bashkortostane [Regarding the issue of ethnic differentiation in Bashkortostan]. Sotsiologicheskie issledovaniia, no. 8, pp. 56-60. (In Russ.).

Lapin, N. I. (2014) Problemy formirovaniia kontseptsii i chelovecheskikh izmerenii strategii poetapnoi modernizatsii Rossii i ee regionov [Issues of concept and human dimensions making of the gradual modernization strategy for Russia and its regions]. Sotsiologicheskie issledovaniia, no. 7, pp. 8-19. (In Russ.).

Markarian, V. R. and Murashko, S. Ph. (2016) Etnos i etnicheskaia identichnost' kak resurs sotsial'no-ekonomicheskogo razvitiia regiona [Ethnos and ethnic identity as a resource for socio-economic development of the region]. Etnosotsium $i$ mezhnatsional'naia kul'tura, no. 6 (96), pp. 60-68. (In Russ.).

Pavlov, K. V. (2016) Etnomenedzhment kak sostavnaia chast' etnoekonomiki [Ethnomanagement as a part of ethnoeconomy]. Vestnik Instituta ekonomicheskikh issledovanii, no. 2 (2), pp. 13-28. (In Russ.).

Perova, E. Yu. (2016) Etnicheskaia ekonomika kak napravlenie povysheniia effektivnosti ispol'zovaniia sotsial'nykh resursov regiona [Ethnic economy as a way to boost effective use of regional social resources]. Izvestiia Baikal'skogo gosudarstvennogo universiteta, vol. 26, no. 5, pp. 705-712. (In Russ.).

Pechura, O. V. (2009) Etnicheskii faktor v razvitii ekonomiki regiona [Ethnic factor in the development of the region's economy]. Izvestiia Ural'skogo gosudarstvennogo ekonomicheskogo universiteta, no. 2 (24), pp. 138-143. (In Russ.).

Popkov, Yu.V.(2020) Sovremennaia rossiiskaia natsional'naia politika: kontseptual'no-tselevye osnovy i opyt realizatsii (na primere Tuvy) [Contemporary Russian national policy: Conceptual and target bases and implementation experience (The case of Tuva)]. New Research of Tuva, no. 3, pp. 253-268. (In Russ.). DOI: https://doi.org/10.25178/nit.2020.3.18

Popkov, Yu. V. and Tiugashev E. A. (2018) Etnokul'tura i ekonomika: sinergiia vozmozhnostei [Ethnoculture and economy: Synergy of opportunities]. EKO, no. 5, pp. 8-27. (In Russ.).

Popod'ko, G. I. (2017) Puti preodoleniia neravenstva sotsial'no-ekonomicheskogo razvitiia otstalykh regionov (na primere Respubliki Tyva) [Ways to overcome the inequalities of socio-economic development of backward regions: Evidence from the Republic of Tuva]. Regional'naia ekonomika: teoriia i praktika, no. 2, pp. 315-328. (In Russ.). DOI: https://doi.org/10.24891/re.15.2.315

Salchak, A. R. (2020) Analiz sostoianiia rynka truda Respubliki Tyva [Analysis of the state of the labor market in the Republic of Tuva]. Ekonomika: vchera, segodnia, zavtra, vol. 10, no. 7A, pp. 191-200. (In Russ.).

Samba, A. D. (2020) Osnovnye izmeneniia v sotsial'no-trudovom prostranstve Respubliki Tyva [Major changes in the socio-labor space of the Republic of Tuva]. Ekonomika i upravlenie: nauchno-prakticheskii zhurnal, no. 1, pp. 47-50. (In Russ.). DOI: https://doi.org/10.34773/EU.2020.1.12

Sotsial'noe neravenstvo etnicheskikh grupp: predstavleniia i real'nost' [Social inequality of ethnic groups: Perceptions and reality] (2002) / ed. by L. M. Drobizheva. Moscow, Academia Publ. 480 p. (In Russ.).

Sotsial'no-stratifikatsionnye protsessy $v$ Respublike Tyva [Socio-stratification processes in the Republic of Tuva] (2020) / Z. T. Golenkova et al., ed. by Z. T. Golenkova, Yu. V. Goliusova and P. E. Sushko. Moscow ; Kyzyl, FCTAS RAS. 128 p. (In Russ.). DOI: https://doi.org/10.19181/monogr.978-5-89697-332-4.2020

Tarbastaeva, I. S. (2018) Tuva prevrashchaetsia v monoetnichnyi region: riski i perspektivy [Tuva's transformation into a monoethnic region: Risks and possibilities]. EKO, no. 5 (527), pp. 65-80. (In Russ.).

Tishkov, V. A. (2005) Rynochnaia ekonomika i etnicheskaia sreda [Market economy and ethnic environment]. Obshchestvo i ekonomika, no. 12, pp. 20-37. (In Russ.).

Trud, zaniatost' $i$ chelovecheskoe razvitie: Doklad o razvitii chelovecheskogo potentsiala v respublike Bashkortostan [Labor, employment and human development: A report on human development in the Republic of Bashkortostan] (2015) / R. M. Valiakhmetov, A. M. Allaiarova, M. V. Artamonova et al. Ufa, Vostochnaia pechat' Publ. 360 p. (In Russ.).

Faizullin, F. S. and Faizullin, T. F. (2014) Regional'nye osobennosti sotsial'nogo razvitiia etnicheskikh obshchnostei [Regional features in the social development of ethnic communities]. Vestnik Akademii nauk Respubliki Bashkortostan, vol. 19, no. 3, pp. 67-75. (In Russ.). 
НОВЫЕ ИССЛЕДОВАНИЯ ТУВЫ

www.nit.tuva.asia
THE NEW RESEARCH OF TUVA

2021

Novye issledovaniia Tuvy

Chetyrova, L. B. (2019) Transformatsiia truda v postsovremennom mire: resursy integratsii etnicheskoi trudovoi kul'tury (na primere Tuvy i Kalmykii) [The transformation of work in the postmodern world: Resources for integrating ethnic work culture (The case of Tuva and Kalmykia)]. New Research of Tuva, no. 3, pp. 77-88. (In Russ.). DOI: https://doi. org/10.25178/nit.2019.3.7

Submission date: 12.10.2021. 